\title{
Improving English Pronunciation Through Computer-Assisted Programs In Jordanian Universities
}

Fatima Zaki Mohammad Al-Qudah, Al-Balqa University, Jordan

\begin{abstract}
The purpose of this research is to investigate the effect of using computer-assisted programs for teaching English pronunciation on students' performance in English Language pronunciation in Jordanian universities. To achieve the purpose of the study, a pre/post-test was constructed to measure students' level in English pronunciation. The sample of the study consisted of 149 third year students; (73) male students and (76) female students from Al Zaytoonah university during the second semester of the academic year 2010/2011. The subjects of the study were distributed into two groups (experimental and control). The experimental group was trained on English pronunciation using computer-assisted program while the control group was trained using the printed material. Descriptive statistical analyses were used (means and standard deviation) for the pre and post- tests of students' English pronunciation. Comparison statistical methods were used (Two Way ANOVA) analysis of variance to make a comparison between the control and the experimental groups and gender variable (male and female). The findings of the study indicated that there were statistically significant differences in the post- test between the control and the experimental groups in favor of the experimental group, and there was no statistically significant difference in the students' performance due to gender.
\end{abstract}

Keywords: Computer-Assisted Program for Teaching Pronunciation; Jordanian Universities; CAPT Software; ESL

\section{INTRODUCTION}

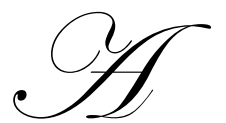

utomatic speech processing have been allowed be incorporated into pronunciation teaching by developments in technology (Hua, 2006). Advantages of computer assisted pronunciation training (CAPT) software for enhancing English learners' pronunciation have been investigated by a number of researchers (e.g. Neri, Strik \& Boves 2002; Butler-Pascoe \& Wiburg, 2003; Kim, 2006). Students were provided by the untiring work of the computer with unlimited opportunities to review any part of the materials and get further assistance offered by the system. Computer assisted pronunciation training software helps students in selecting what function to employ and how often they utilize it and also it helps them to study independently. However, deploying CAPT language teachers also benefit from software in their pronunciation classes since it can give students drilling practice, which language instructors' view as monotonous and time-wasting. Finally, computer assisted pronunciation training systems present an interactive learning context in a range of modes: whole class, small group or pair, and teacher to student (Pennington, 1999).

This software has some drawbacks, although it has a lot of advantages. Most researchers criticize the CAPT software because it was developed without a foundation in any pedagogical theory (Hua, 2006). Some researchers such as Pennington (1999) indicated that most computer assisted pronunciation training software placed emphasis on the mechanics of articulation which are not contextualized. Seferoğlu (2003) stated that -one of the main limitations of many of the computer assisted pronunciation software packages is that they are limited to presenting and practicing of segmental aspects (i.e. individual sounds) of the language rather than suprasegmental aspects and connected speech. The development of much of the computer assisted pronunciation training software has also been found to concentrate on the powerful multimedia facilities of computers and to lack content that is linguistically and pedagogically complete (Derwing \& Munro, 2005; Neri et al., 2002; Reeser, 2001). 
Traditionally printed materials, such as course information, exercises, lecture notes, quizzes, and others were substituted by many pronunciation teachers by employing computer-assisted materials. Teachers make pronunciation materials available to students through the electronic medium by altering the way in which students receive L2 specific phonological input instead of distributing them in the form of printed handouts in the language classroom. Internet-based materials are viewed today as not only technological but also pedagogical devices to improve pronunciation teaching and the learning process. Because computer assisted materials offer minimal pairs, sound animations, tongue twisters, step-by step phonetic descriptions, songs, and video animations specific to segmental (i.e. consonant and vowel phonemes of English) and suprasegmental (i.e. pitch, loudness, tempo, and rhythm) aspects of English pronunciation, they have attracted pronunciation teachers who are willing to infuse colorful, natural, and interesting teaching materials into their lessons (Hişmanoğlu, 2010).

\section{Statement of the problem}

Having observed some classes for teaching English language at some Jordanian universities in Amman, the researcher noticed that students most often pronounce English sounds in a wrong way. They lack the motivation for learning English pronunciation. To solve this problem the researcher aims at using computer-based program and investigates its' effect on students' performance in English language pronunciation.

\section{Significance of the study}

Many researchers are interested in using computers as a medium for teaching and learning. Therefore, many studies have been conducted on using computer assisted programs for teaching English. To the researchers' best knowledge; a few studies were conducted on using computer assisted programs in teaching English pronunciation in Jordanian universities. The current study focused on the effect of using computer-assisted program for teaching pronunciation on students' performance in English language.

\section{Purpose of the study}

The purpose of this research is to investigate the effect of using computer- assisted programs for teaching pronunciation on Jordanian students' performance in English Language pronunciation in Jordanian universities; it also seeks to study the effect of the gender.I

\section{Questions of the study}

The questions of the study are:

- $\quad$ Are students who are taught English pronunciation via computer-based pronunciation materials better at pronouncing English sounds than those taught English pronunciation via printed pronunciation materials?

- $\quad$ Are there any statistically significant differences $(\alpha \leq 0.05)$ in the Jordanian university students' performance in English Language pronunciation due to gender?

\section{Limitations of the study}

This study is limited to the male and female third year students at Al Zaytoonah University in Jordan 2010/2011, and to any other similar samples.

\section{LITERATURE REVIEW}

The amount of importance that has been attributed to L2 pronunciation teaching over the past fifty years has altered remarkably as have the views on the extent to which non-native pronunciation mistakes should be corrected (Busa, 2008). The goal of foreign language pronunciation instruction was the achievement of a native-like accent, as modeled by the language teacher in the 50 's and $60^{\circ} \mathrm{s}$, when the audio-lingual approach was very popular. Pronunciation instruction, in this period, was based on the discrimination and production of sounds as a way of developing the recognition and articulation of foreign language specific sounds (Lambacher, 1996). 
There were many commenced to question the importance of an instructional focus on pronunciation in the foreign language classroom from the late 1960 `s to 1980 `s. Some speculated that native-like pronunciation was an unattainable goal in a foreign language (Preston, 1981). The pronunciation instruction was reduced by many language programs or eliminated it altogether. There was a reconcentration on pronunciation in the late 1980's (Morley, 1991). People commenced to concentrate on supra-segmental Instead of mimicry (i.e. stress, pitch, juncture, and intonation), sound co-articulation and voice quality of learning a new language (Esling \& Wong, 1983). The goal became attaining communicative competence, a foreign language learners' ability to not only apply and utilize grammatical rules, but to generate pragmatically appropriate utterances and employ them suitably in a given context. This new shift in pronunciation included less emphasis on correct articulation of foreign language specific sounds (vowels and consonants) although this new shift in pronunciation teaching maximized meaningful interaction (Morley, 1991; Pennington \& Richards, 1986).

Pronunciation, especially foreign language pronunciation, gained new meaning after 1980 's due to its fruitfulness to a broad group of international people in both ESL and EFL settings (Derwing \& Munro, 2005; Gatbonton, 2005;). academic professionals, other professionals all over the world and students needed to develop their pronunciation because they left their native countries to accommodate in or visit English speaking countries to embrace cultural, financial, and economic opportunities ( Chaudhary, 2009; Derwing \& Munro, 2009).

Many language teachers have begun to employ technology as an aid to English pronunciation teaching recently (Neri, Cucchiarini, \& Strik, 2006; van den Doel, 2007). Media, cell phones and computer programs are becoming more widely infused into pronunciation classrooms as tools for fostering English pronunciation (Haslam, 2010).

The number of applications available to both the teacher and the individual learner is increasing rapidly due to advances in research into language and speech, increased computer capabilities and lower computer costs. In this vein, automatic speech recognition and speech synthesis, two of the most common applications in speech technology, present the basic technology for the improvement of applications for pronunciation teaching (Busa, 2008).

Today, a number of interactive commercial pronunciation teaching products such as CD-based and internet programs are on the market. While some of these products are CD-based, some are delivered over the internet.

\section{DESIGN AND METHODOLOGY}

The researcher discussed here the procedures that she used to conduct the study. She described the study population, sample, variables, instrument, procedures and the statistical analyses that she used in the study.

\section{Population of the study}

The population of the study will consist of:

All third year students of English specialization in Al Zaytoonah university enrolling in the second semester 2010/2011 who form (1869) females and males.

\section{Sample of the study}

The sample of the study consisted of (149) third year students in Al Zaytoonah university,73 male and 76 female students, and they were distributed into two sections, which were selected purposefully. This is a private university and it is well- equipped with technology.

\section{Design of the study}

This study was carried out to follow the equivalent pre /post-test two-group design. The experiment consisted of two levels: The subjects of the experimental group were exposed to the computer-assisted training for 
(8) weeks. However, the subjects of the control group were exposed to the traditional way of training on English pronunciation which is using printed material for the same period. A pre-test was given before the application of the treatment to both groups to make sure they are equivalent and the same test was administered as a post-test after applying the treatment to see whether the computer-assisted training programs had any influence on the experimental groups and which way of instruction have more influence on the subjects than the other.

\section{Instruments}

In this research study, a word list including all English consonants and vowels in various positions in words was used to elicit the pronunciation of the subjects of these English consonants and vowels. During this process, a voice recorder and a $\mathrm{CD}$ were utilized to record the subjects'voices. Lastly, in the course of the implementation, thirty computers with the assisted programs were used to conduct the lessons.

\section{Instructional material}

The instructional material was the third year students' course for English pronunciation

\section{Procedures of the study}

This study was carried out to follow the equivalent pre /post-test two-group design. The experiment consisted of two levels: The subjects of the experimental group were exposed to the computer-assisted programs for (8) weeks. However, the subjects of the control group were exposed to the printed material for the same period.

The researcher used two strategies for teaching English pronunciation: using computer-assisted programs and the conventional way. Then the researcher designed a test based on the instructional material and collected the data.

There were two groups of students: one experimental group and one control group. All groups received 8 weeks of instruction on the English pronunciation. Students in the experimental group received training using computer-assisted program for English pronunciation. They spent all of their class time using computer- assisted programs.

Interactive computer- assisted programs were developed, as research suggests that animated demonstration may be more efficiently processed by learners than non animated demonstration. Therefore, students in the experimental groups had tasks making use of dynamic animated representations on computers. The selected computer assisted programs are interactive and can illustrate a concept through attractive animation, sound, and demonstration. In addition, they allow students to progress at their own pace and to work individually or to do problem solving in a group.

They provide immediate feedback, letting students know whether their answers are correct or not. If an answer is incorrect, the program shows students how to answer the question correctly, and this helps them strengthen their procedural knowledge of English pronunciation. Students in the control group were instructed using conventional way such as printed material.

\section{Statistical analyses}

To answer the study questions, descriptive methods (means and standard deviation) were used for pre and post tests for English language pronunciation test to experimental and control groups.

Comparison statistical method (Two-Way ANOVA) analysis of variance was used to make a comparison between the control and the experimental groups and gender variable (male and female). 


\section{FINDINGS OF THE STUDY}

The purpose of this study is to investigate the effect of using computer-assisted programs for teaching English pronunciation on third year students' performance in English pronunciation in Al Zaytoonah University. The researcher followed the equivalent pre /post test two group designs. Therefore, the means, standard deviations and Two-Way ANOVA analysis of variance were used to analyze data. The results will be displayed based on the questions of the research.

Table 1: Means and Standard Deviations of the Achievement of two Groups on the Pretest

\begin{tabular}{|l|c|c|c|c|}
\hline \multicolumn{1}{|c|}{ GROUP } & SEX & Mean & Std. Deviation & N \\
\hline Experimental & Male & 69.37 & 11.95 & 38 \\
& Female & 69.30 & 9.76 & 37 \\
& Total & 69.33 & 10.85 & 75 \\
\hline Control & Male & 70.40 & 10.63 & 35 \\
& Female & 68.51 & 11.08 & 39 \\
& Total & 69.41 & 10.84 & 74 \\
\hline Total & Male & 69.86 & 11.27 & 73 \\
& Female & 68.89 & 10.40 & 16 \\
& Total & 69.37 & 10.81 & 149 \\
\hline
\end{tabular}

Table (1) shows that the mean for the experimental group is 69.33 while for the control group is 69.41 . It also shows that the mean for male students was 69.86 while for female students it was 68.89 .

To determine if the two groups are equivalent in their English pronunciation, a two-way ANOVA of the pre-test was conducted as shown in table (2).

Table 2: Two- Way ANOVA Results of the Experimental and the Control Groups on the Pretest.

\begin{tabular}{|l|c|c|c|c|c|}
\hline \multicolumn{1}{|c|}{ Source } & Type III Sum of Squares & df & Mean Square & F & Sig. \\
\hline GROUP & .568 & 1 & .568 & .005 & .945 \\
GENDER & 35.656 & 1 & 35.656 & .300 & .585 \\
GROUP * GENDER & 30.664 & 1 & 30.664 & .258 & .612 \\
Error & 17226.715 & 145 & 118.805 & & \\
Corrected Total & 17292.698 & 148 & & & \\
\hline
\end{tabular}

Based on the Two-way ANOVAs on the pre-test, the groups were equivalent. Hence, level of significance is .945 while is not significant at $\alpha \leq 0,05$. Also the groups in terms of gender were equivalent at a level of .585 . This is not statistically significant at $\alpha \leq 0,05$. This means that the groups were equivalent on the pre-test.

At the end of the experiment, a t-test for independent samples was conducted to determine if there was any statistically significant difference between the males and the females on the posttest, which may be attributed to gender. Table 3 shows the results.

Table 3: Mean and Standard Deviations of the Achievement of Male and Female Groups on the Posttest

\begin{tabular}{|c|c|c|c|c|}
\hline GROUP & SEX & Mean & Std. Deviation & $\mathbf{N}$ \\
\hline \multirow[t]{3}{*}{ Experimental } & Male & 82.05 & 8.33 & 38 \\
\hline & Female & 81.95 & 8.89 & 37 \\
\hline & Total & 82.00 & 8.56 & 75 \\
\hline \multirow[t]{3}{*}{ Control } & Male & 78.74 & 9.73 & 35 \\
\hline & Female & 77.77 & 11.37 & 39 \\
\hline & Total & 78.23 & 10.57 & 74 \\
\hline \multirow[t]{3}{*}{ Total } & Male & 80.47 & 9.12 & 73 \\
\hline & Female & 79.80 & 10.38 & 76 \\
\hline & Total & 80.13 & 9.76 & 149 \\
\hline
\end{tabular}

(C) 2012 The Clute Institute http://www.cluteinstitute.com/ 
Table 4 shows the mean and standard deviation of the groups on the post-test. It shows the experimental group at 82.00. While the control group at 78.23. As for the males and females, the males were 80.47 and the female were 79.80 .

The researcher also conducted a two-way analysis of variance to analyze the posttest achievement scores of the two groups. Table 4 shows the results.

Table 4: A Two-way Analysis of Variance of the Achievement of the control and the Experimental Groups on the post test

\begin{tabular}{|l|c|c|c|c|c|}
\hline \multicolumn{1}{|c|}{ Source } & Type III Sum of Squares & df & Mean Square & F & Sig. \\
\hline GROUP & 521.104 & 1 & 521.104 & 5.577 & .020 \\
SEX & 10.851 & 1 & 10.851 & .116 & .734 \\
GROUP * SEX & 6.988 & 1 & 6.988 & .075 & .785 \\
Error & 13547.395 & 145 & 93.430 & & \\
Corrected Total & 14094.577 & 148 & & & \\
\hline
\end{tabular}

To answer the first question: Are students who are taught English pronunciation via computer-based pronunciation materials better at pronouncing English sounds than those taught English pronunciation via printed pronunciation materials? The table shows that the level of significance is .020 which is statistically significant at $\alpha \leq 0,05$ on favor of the experimental group. To answer the second question: Are there any statistically significant differences $(\alpha \leq 0.05)$ in the Jordanian university students' performance in English Language pronunciation due to gender? Table five shows significance .734 which means it is not significant at $(\alpha \leq 0,05)$

To sum up, the researcher believes that the difference in the performance of the third year students was attributed to the using of computer-assisted programs for teaching English pronunciation. The experimental group participants managed to significantly improve English pronunciation in a period of 8 weeks. The improvement achieved by the control group subjects, however, was not statistically significant. By comparing the results achieved by the two groups, the researcher reached the conclusion that the improvement achieved by the experimental group may have been attributed to the way he rendered instruction; using computer-assisted programs.

As a result of this experience, the researcher concluded that students were more engaged in learning when they were given a chance to use computer to train on English pronunciation.

\section{CONCLUSION}

After treatment, the experimental group got higher mean scores than the control group. The study also showed that there was statistically significant difference in a post-test between the control group and the experimental group in favor of the experimental group and this means that the using of computer-assisted programs for training students on English pronunciation is better than using the conventional way which is printed material in developing students' performance. It is evident that the experimental group performed much better on the post-test than the control group. Thus, it could be concluded that the students who were trained by using computer-assisted programs scored significantly higher in the post-test than the students who were trained by using printed material at $(\alpha=0,05)$. The findings of the study indicated that there was no statistically significant difference in the students' performance due to their gender.

\section{AUTHOR INFORMATION}

Fatima Zaki Mohammad Al-Qudah teaches English at Al-Balqa University in Jordan. Email: fatima_hjq@yahoo.com

\section{REFERENCES}

1. Brown, K. (2003). From teacher-centered to learner-centered curriculum: Improving learning in diverse classrooms. Education 124:49-54. 
2. Busa, M. (2008). New Perspectives in Teaching Pronunciationll. Retrieved September 15, 2011, from http://etabeta.univ.trieste.it/dspace/bitstream/ 10077-2850.

3. Butler, P. Mary, E. \& Wiburg, K (2003). Technology and teaching English language learners. MA: Pearson Education, Inc.

4. Derwing, T. \& Munro, M. (2005). Second language accent and pronunciation teaching: A research-based approach. TESOL Quarterly 39:379-397.

5. Derwing, T. \& Munro, M. (2009) Putting accent in its place: rethinking obstacles to communication. Language Teaching 42:476-490.

6. Esling, J. \& Wong, R. (1983). Voice quality settings and the teaching of pronunciation. TESOL Quarterly 17:89-95.

7. Haslam, N. (2010). The Relationship of Three L2 Learning Factors with Pronunciation Proficiency: Language Aptitude, Strategy Use, and Learning Context. Unpublished master`s thesis. Brigham Young University.

8. Hişmanoğlu, M. (2010). Online Pronunciation Resources: Hobbies or Fobbies of EFL Teachers? IJONTE, $1(2), 40-53$.

9. Hua, T. (2006). Bridging pedagogy and technology: User evaluation of pronunciation oriented CALL software. AJET 22:375-397.

10. Kim, I. (2006). Automatic speech recognition: Reliability and pedagogical implications for teaching pronunciation. Educational Technology \& Society 9:322-334.

11. Lambacher, S. (1996). Teaching English Pronunciation Using a Computer Visual Display. Paper presented at the IATEFL 29th Inter-national Annual Conference, York, England, 1995. Retrieved at: http://www.uaizu.ac.jp/ steeve/york95.html.

12. Morley, J. (1991). The Pronunciation Component in Teaching English to Speakers of Other Languages. TESOL Quarterly 25:491-520.

13. Neri, A., Cucchiarini, C., Strik, H. \& Boves, L. (2002). The pedagogy-technology interface in computer assisted pronunciation training. Computer Assisted Language Learning 15:441-467.

14. Neri, A., Cucchiarini, C., Strik, H. (2006). Selecting segmental errors in L2 Dutch for optimal pronunciation training. IRAL 44:357-404.

15. Oxford, R. (2003). Language learning styles and strategies: Concepts and Relationships. IRAL 41:271-278.

16. Pennington, M. (1999). Computer-aided pronunciation pedagogy: Promise, limitations and directions. Computer Assisted Language Learning 12:427-440

17. Pennington, M. \& Richards, J. (1986). Pronunciation revisited. TESOL Quarterly 20:207-225.

18. Preston, D. (1981). The ethnography of TESOL. TESOL Quarterly 15:105-16.

19. Reeser, T. (2001). CALICO Software Review: Tell Me More-Frenchll. Retrieved September 30, 2011 from http://calico.org/CALICO

20. Seferoğlu, G. (2003). Improving students‘ pronunciation through accent reduction software. British Journal of Educational Technology 36:303-316.

21. Van den Doel, R. (2007). Native vs. non-native attitudes to non-native Englishes: Implications for English as an International form of communication. Paper presented at 1st International Conference on English, Discourse and Intercultural Communication, Macao Polytechnic Institute, 8th to 10th July, 2007, and Urumqi, 11th to 14th July, 2007. 
NOTES 